\title{
Employee Monitoring: Workplace as a Panopticon?
}

\author{
An STS Research Paper \\ presented to the faculty of the \\ School of Engineering and Applied Science \\ University of Virginia
}

by

Yuhuai Liu

March 28, 2017

On my honor as a University student, I have neither given nor received unauthorized aid on this assignment as defined by the Honor Guidelines for Thesis-Related Assignments.

Signed:

Approved:

Date

Peter Norton, Department of Engineering and Society 


\section{Employee Monitoring: Workplace as a Panopticon?}

In a survey conducted by American Management Association (AMA) (2007), 66 percent

of 304 U.S. companies reported that they actively monitor Internet connections, while 43 percent monitor email and at least 45 percent monitor telephone and voicemail. As Internet connections have become indispensable for work, electronic devices with network connection are now prevalent in workplaces. Employers can now easily monitor employees' activity during work hours. Many have compared workplaces under such monitoring to the Panopticon.

The Panopticon is a design for a prison first described in Jeremy Bentham's letters to an English correspondent in late 18th century. In the letters, the Panopticon is described as a circular building in which each individual cell is separated and occupies the circumference of the building (Božovič, 2011). Bentham also mentioned the "inspector's lodge" sitting at the center of the circle, from where the prison guard can see all the prisoners at all times (Božovič, 2011).

Foucault (2009) concluded that the major effect of the Panopticon is "to induce in the inmate a state of conscious and permanent visibility that assures the automatic functioning of power." Such surveillance "is permanent in its effects, even if it is discontinuous in its action" (Foucault, 2009). Therefore, he coined the concept of Panopticism and extended the applications for what was only meant to be a practical design for incarceration to social control, under which "factories, schools, barracks, hospitals ... all resemble prisons" (Foucault, 2009).

Meanwhile, the modern work environment had been changing rapidly since the late 18th century and managers needed new methods for exerting control in the workplace. Frederick W. Taylor and his philosophy of "scientific management" soon become "very attractive to business people and to technocratic intellectuals outside business" (Waring, 1991). Essentially, Taylorism 
encourages managers to be scientific and invent means for diminishing waste and conflict (Waring, 1991). Some suggest "men like Taylor" want to "discover a 'a law of human fatigue' which would allow them to extract everything possible from living labour short of killing the individual who performed it" (Godelier, 1988). In describing the "four elements which constitutes the success of scientific management" of Frank Gilbreth's bricklaying system, Taylor highlights the combination of first-class bricklayers with science of bricklaying through "help and watchfulness of management" (Taylor, 1914). Keeping an eye on employees is essential to functioning management. Employee monitoring, whatever its form, became a primary means to increase productivity and efficiency.

In such a context, combined with the supposed all-seeing ability of surveillance software, the modern workplace, in which software vendors, employers, enforcers (system admins) and employees are participants, resembles what Foucault had in mind. What are the effects of prevalent surveillance on employees? Is the modern workplace a Panopticon where employees are prisoners and employers the all-seeing guards? We conclude the answer is yes.

\section{Review of Research}

According to Mishra \& Crampton (1998): "the issue of employee monitoring has emerged recently because of employee privacy rights." There is almost no legal protection against such monitoring, despite implicit constitutional guarantees of privacy. The Fourth Amendment usually protects citizens' privacy from state actions (Nord et al., 2006). But private sector workers must instead resort to state or federal law, notably the Electronic Communications Privacy Act (ECPA). Even under ECPA, however, three exceptions "effectively eliminate any 
substantial expectation of privacy an employee might have with respect to his/her employer" (Nord et al., 2006). In 1996, Michael A. Smyth sued the Pillsbury Company for discharging him for a rude comment he sent over the company's email system. The court ruled for the defendant, finding that "to the extent that Smyth did have a privacy interest in the e-mails, the company's interest in preventing inappropriate and unprofessional behavior outweighed that interest" (Muhl, 2003).

Despite encroachments on privacy, most companies monitor their employees to some degree. Lasprogata et al. (2004) attribute monitoring to ten perceived benefits. These benefits can be put into three broad categories: increased organizational security, reduced corporate liability and maximized employee productivity. Martin \& Freeman (2003) concur, adding that "monitoring changes the way individuals act when they are not being watched," an argument rooted in Jeremy Bentham's Panopticon, where perpetually watched inmates would eventually internalize the guard's rules. According to Rosenblat et al. (2014), under the influence of Taylorism, workplaces are designed so that "workers would internalize their boss' gaze" and employers are "genuinely trying to get inside employees' heads." Examining payment systems in call centers, Fernie \& Metcalf (1998) argued that “for call centres, Bentham's Panopticon was truly the vision of the future and these organizations are the very epitome of what Foucault had in mind."

Taylor \& Bain (1999) contend that employees can resist workplace monitoring, thwarting internalization of the gaze. Smith \& Thompson (1998) argue scholars confused characteristics of workplace monitoring system and managers' intentions with actual effects on workers. 
Indeed, the effects of workplace monitoring vary. Studying the well-being of employees in call centers, Holman et al. (2002) found that "when clear performance criteria are developed and when positive feedback is given regularly, the monitoring system will be associated with greater well-being," but that "the perceived intensity of monitoring had a strong negative association with all four measures of well-being." Alder et al. (2006) found that perceived support from the company and advanced notice of monitoring contribute to post-implementation trust between employees and employers. However, such results are consistent with the internalization argument.

Researchers have investigated how internalization works. Kelman's (1958) theoretical framework identifies three processes of attitude change due to social influences: compliance, identification and internalization. According to Kelman (1958), compliance occurs when an individual "hopes to achieve a favorable reaction from another person or group," while internalization occurs when "the content of the induced behavior ... is intrinsically rewarding." Compliance can lead to internalization because "behaviors can eventually change attitudes" (Fogg, 2011).

\section{What Constitutes a Panopticon?}

Discussions on modern surveillance often use the Panopticon metaphor without proper qualification. With vague reference to legal reasoning, we could qualify modern workplaces as Panopticons if and only if we can establish both intent of employers to induce compliance and actual effect on employees. With other participants in mind, four questions are to be answered: 
1. Do employers and software vendors intend to induce compliance through monitoring?

2. Do employers have the all-seeing ability with the help of software?

3. How do enforcers (system admins) identify themselves in the process?

4. What actual effect does monitoring have on employees?

\section{Intention to Induce Compliance}

Productivity, security and liability are three manifest concerns for workplace surveillance. For example, Motorola (2015), a corporate solution provider who supports "fleet management," claims that tracking staff's real time location increases efficiency in staff management. Fortscale produces software that monitors digital footprints to detect security breaches within the organization, because "an insider spy is perhaps the most significant threat to enterprise security" and "monitoring their behavior is a critical component in detecting and deterring their activities" (Bosen, 2016). PricewaterhouseCoopers (PwC) (2011), an auditing and consulting firm, prescribes "monitoring of electronic communications, as well as tailored post-trade surveillance" for a hedge fund to protect against insider trading.

Employers are less candid about why surveillance is effective. But software vendors are not at all reluctant to advertise by appealing to their motives. For example, while stating organizations may use surveillance to investigate incidents reactively, SpecterSoft (n.d.) acknowledges the "Proactive Protection Strategy" to "ensure adherence to company policies, and improve awareness about what is happening with the company." "In most cases," claims Teramind (n.d.a), “just letting the employee know they're being monitored can change their behavior to follow company policies." Vendors know risk and liability can hardly be reduced by 
only reprimanding offenders and making remedies after the fact. Nor can productivity and efficiency be increased if only slackers are disciplined. To achieve intended effects, employees must know they are being monitored and thus have no expectation for privacy.

This is evident in employers' official policies. According to Verizon's (2015) Code of Conduct, the company can monitor all use of company systems. Hershey (n.d.), under the heading of code of conduct that says "Having No Expectation of Privacy," warned employees that their use of company resources is not private. Even though "it is generally not [their] practice to monitor" use of information systems, PepsiCo (n.d.) still claim the right to do so in their document.

The reason employers choose to reserve the right to monitor their information system has to do with organizational compliance, the practice to prevent violations of any external legislation or policies. Therefore, a company also wants its employees "to be sensitive to legal requirements in order to minimize the threat of legal sanctions and reputational harm that it faces when a violation occurs," according to Langevoort (2002). By eliminating employees' reasonable anticipation for privacy in the workplace, employers are actually inducing in employees compliance with policies, internal or external. In other words, compliance is not a latent function of monitoring in the workplace, but rather a function not directly manifested.

\section{Ability to See All}

In Bentham's Panopticon, the placement of inspector's lodge lets prison guards see every prisoner's action all the time. In the modern workplace, management is bestowed with the same capability thanks to monitoring software. 
Employee monitoring software often includes features of two types: passive or active. Passive features include keylogging, screen capture, network monitoring, filesystem monitoring and activity monitoring. Active features include blocking of webpages and termination of processes. These features are seldom deployed individually, but often work together to ensure compliance with company policies. In Teramind's (n.d.b) live demo, aside from being able to view in real time the screen of an employee, users can also set rules and triggers to receive alerts for specific activities. For example, user can set a rule for detecting website whose URL contains words like "Youtube," "Facebook," or "Instagram." If an employee stays on such website for more than 15 minutes, an alert would be sent to the administrator. Alerts could also be sent if employees search keywords like "money laundering" or "cocaine dealers." The surveillance on filesystem is even more pervasive. Veriato (n.d.) promises to track creation of new files and editing or printing of existing files, which means it is capable of monitoring the operating system for all reading and writing of the filesystem.

This is not to say that such ability has no limit. Real-time monitoring and collection of data require extra computation power to run background process, sufficient network bandwidth to transmit data and ample storage space to store them. Not every organization can afford the resources to maintain such a system. Therefore, vendors have to limit some functionalities by only transmitting and storing data when a risk is observed, or activate monitor when certain criteria is met. However, as computer processors, network infrastructure and storage devices become cheaper and better over time, the limit would eventually be rendered meaningless, thus granting the management real ability to see all, at all times, in real time. 


\section{Self-identification of Enforcers}

In an organizational environment, it is often not the management who directly uses the monitoring software but the system admins due to its inherent technical nature. If the modern workplace is indeed a Panopticon, system admins play the role of prison guard to enforce the company policies.

In the comment section of a Lifehacker article proposing various methods to evade electronic monitoring, some readers draw from their experience of being a system administrator to express their dissent. A major theme among these comments is their responsibility to protect the system through monitoring because " "monitoring' is really 'security' in the IT world" (momoceio, 2012). While many readers admit no interest in keeping an eye on every activity of end users, they would nevertheless report an employee to the management if his or her behavior causes them trouble. According to Michael Furman, he only goes after users because "these are the same folks who mule in virus and other crap and put it on the network for me to stamp out" (Michael Furman, 2012). "Ruin my life and I'll ruin yours," says an emotional reader, “the only way I'm reporting that you're checking your gmail is if you're 'that user' who causes me trouble by infecting us with viruses, installing 50 IE toolbars" and many other offenses (zipobibrock5e8, 2012). For system admins, their job is dependent on whether the system is secure. A disobedient user is as much a threat to the system as a software bug.

To further express grievances against troublemakers, some state that employees should not be concerned about monitoring unless they are behaving questionably (momoceio, 2012). Such an argument often follows the same reasoning: "If you are doing your job and doing nothing against policy, why would you care if you're monitored or not?" (f-meinthea, 2012) Meanwhile, they are also eager to point out that it is corporate property that they are monitoring, 
therefore employees should never expect privacy while working with it (monkeybusiness; epon, 2012), an argument that bears a striking resemblance with companies' code of conducts. Hence, any challenge to the existing rule could be view as evidence of ulterior motive, even though some users have genuine concern or need for privacy.

Despite the flaw in the argument, such reasoning nevertheless reflects system admins' intention for employees to comply. System admins are supposed to support other colleagues. By giving them the responsibility of surveillance, organizations are in fact pitting them against other employees, an antagonistic relationship not unlike the ones between the prisoners and prison guards. Because their job security is likely to be harmed by offenders and they have the capability to keep an eye on them, monitoring softwares also gives system admins the intention and ability to ensure compliance. With such ability and intention, system admins identify themselves as enforcer of rules, which is what prison guards are.

\section{Effect on Employees}

The Panopticon argument remains invalid if employees do not become compliant as a result of monitoring. Even though a compliant employee does not necessarily consider himself or herself as a prisoner trapped in the workplace, his or her behavior is still influenced by employee monitoring.

There has been much literature on how monitoring reduces the amount of unwanted behaviors. But a less obvious behavior change is the constant assumption of being monitored, even though a company does not monitor or the monitoring is not continuous, as shown by employees responding to the same Lifehacker article. "Assume you are being monitored, because you probably are, and act accordingly," says a reader (jbarr, 2012). Under the post discussing 
monitoring on Wall Street Oasis, a forum for financial industry workers, several users agree that employees should always assume corporate compliance is reading their emails (KPP, 2012).

Such assumption comes from not only the prevalence of monitoring in the workplace but also the ability of monitoring systems to keep a record of everything they monitor. And the result of the assumption could be compliance, or at least the pretension of which under surveillance.

Another more obvious change in behavior is to adopt various evasive techniques. These techniques range from some purely non-technical, and perhaps humorous, ones like befriending the system admins (Commuter, 2012), to some quasi-technical ones, like using their own device (gamenumbers, 2012), to some very technical methods only applicable to tech-savvy users. One user installed another operating system (OS) on his company computer and would use that OS solely for browsing the web (bdslack, 2012). VPN and proxy servers and softwares like Tor are also proposed to circumvent monitoring of company networks (Kenny Powers, 2012).

These individual forms of resistance are an updated version of part of what Taylor \& Bain describes about call center employees in their 1999 essay and argues to be a reason why the Panopticon argument is in trouble. But these techniques are often ineffective. System admins are unlikely to neglect their responsibility or job security "even for a lot of beer" because it is like to expect "your bank security friend ... to tell you which cameras don't work" (Bogus Maximus, 2012). Using their own devices seems to be an effective measure only if they are permitted in the workplace, and some companies in the financial sector even prohibits the use of cellphone within the company (marcellus_wallace, 2013). Even the heavily technical methods fail because of network system technicalities, and here is why:

In an organizational environment, not every device is directly connected to the Internet, but rather through a network gateway, an aptly named set of devices that acts both as a link and a 
barrier between the organizational private network and the rest of the cyberspace. Employee

monitoring software is installed on every device and it works with its counterpart on the gateway to collect data. Because network packets to and from the Internet go through the gateway, monitoring softwares have access to every one of them. Even if encryption is used, in case of using Tor or VPN softwares, monitoring softwares may not make sense of those packets, which for many organizations is an immediate red flag for system admins. The only way to evade such monitoring is to use your own device operating outside of the organizational network.

Taylor \& Bain (1999) also mentioned trade unionism as a form of collective resistance and cited the improvement of conditions in call centers as success. While unions challenge workplace monitoring, their agenda does not pose enough challenge to the status quo. For example, the Massachusetts Nurses Association and other professional groups resist monitoring in the workplace, and they seek protection through collective bargaining of contracts for, among others, prior notice and "a limit on the monitoring to a 'reasonableness standard' with specific work related reasons (patient privacy, investigation of potential misconduct or illegal activity)" (Twarog, 2005). However, prior notice may become another method to eliminate employees' expectation of privacy. As for limiting surveillance to specific work related reasons, employers can always justify their methods with formerly identified manifest functions of monitoring while refusing to acknowledge the implicit intention of inducing compliance.

\section{Conclusion}

Generally speaking, organizations have the natural tendency to induce compliance because "compliance to authority is an integral part of how organizations operate," according to Karakostas \& Zizzos (2016). Electronic monitoring in the workplace could be viewed as yet 
another method towards that end. With system admins identifying themselves as the enforcer of rules with the help of monitoring softwares, employees assume they are constantly under surveillance, the kind of permanent effect Foucault concludes about the Panopticon. Panopticism as a form of social control has been implemented in our everyday workplace of modern time.

Foucault in 1975 discovered the inherent link between the Panopticon and the workplace. According to Foucault (2009), discipline is a tactic of power to achieve three goals: to execute power economically, to maximize effects of power, and "to link this 'economic' growth of power with the output of the apparatuses (educational, military, industrial or medical) within which it is exercised." Not only was this needed due to the population growth after the 18th century, but also "the growth in the apparatus of production," whose increasing complexity and costs demand more profit (Foucault, 2009). It explains the motives behind the entire "scientific management" movement, and perhaps more importantly, guarantees the forming of Panopticons in modern workplaces.

The troubling assumption behind Panopticism is the necessity to sacrifice privacy for other benefits. We can see assumptions alone the same line in the ongoing debate over government mass surveillance, which supposedly boosts collective security at the expense of individual privacy. The implicit reasoning pitting privacy against productivity and security is that privacy means the secrecy of discreditable facts of ones wrongdoing, a position Solove (2007) strongly opposes. Such narrow definition of privacy is convenient for social and corporate governance, but inconvenient for our ongoing inquiry in the role of privacy in human society. 


\section{References}

Alder, G. S., Noel, T. W., \& Ambrose, M. L. (2006). Clarifying the effects of Internet monitoring on job attitudes: The mediating role of employee trust. Information \& Management, 43(7), 894-903.

American Management Association (2007). 2007 Electronic Monitoring \& Surveillance Survey. November 02, 2016, http://www.epolicyinstitute.com/2007-survey-results

Bdslack. (2012, March 20). How Can I Tell If I'm Being Monitored at Work and What Can I Do About It? [Article comment]. http://lifehacker.com/5894689/how-can-i-tell-if-im-being-monitored-at-work-and-whatcan-i-do-about-it

Bogus Maximus. (2012, March 20). How Can I Tell If I'm Being Monitored at Work and What Can I Do About It? [Article comment]. http://lifehacker.com/5894689/how-can-i-tell-if-im-being-monitored-at-work-and-whatcan-i-do-about-it

Bosen, B. (2016). How to detect an Insider Spy. November 03, 2016, https:/insider.fortscale.com/detecting-an-insider-spy/

Božovič, M. (Ed.) (2011). The panopticon writings. London: Verso.

Commuter. (2012, March 26). How To Block Your Employer's Monitoring [Reply to post]. https://www.wallstreetoasis.com/blog/how-to-block-your-employers-monitoring

Epon. (2012, March 20). How Can I Tell If I'm Being Monitored at Work and What Can I Do About It? [Article comment]. http://lifehacker.com/5894689/how-can-i-tell-if-im-being-monitored-at-work-and-whatcan-i-do-about-it

Fernie, S., \& Metcalf, D. (1998). (Not) hanging on the telephone: payment systems in the new sweatshops. Centre for Economic Performance, London School of Economics and Political Science.

F-meinthea. (2012, March 20). How Can I Tell If I'm Being Monitored at Work and What Can I Do About It? [Article comment]. http://lifehacker.com/5894689/how-can-i-tell-if-im-being-monitored-at-work-and-whatcan-i-do-about-it 
Fogg, B. J. (2011). Persuasive technology: using computers to change what we think and do. Amsterdam: Morgan Kaufmann.

Foucault, M. (2009). Discipline and punish: the birth of the prison (A. Sheridan, Trans.). New York: Vintage. (Original work published 1975)

Gamenumbers. (2012, March 26). How To Block Your Employer's Monitoring [Reply to post]. https://www.wallstreetoasis.com/blog/how-to-block-your-employers-monitoring

Godelier, M. (1988). Foreword. In B. Doray, From Taylorism to Fordism: a rational madness (D. Macey, Trans.). London: Free Association Books

Hershey. (n.d.). Code of Ethical Business Conduct.

March 17, 2017, https://www.thehersheycompany.com/content/dam/corporate-us/documents/investors/ business-code-of-conduct.pdf

Holman, D., Chissick, C., \& Totterdell, P. (2002). The effects of performance monitoring on emotional labor and well-being in call centers. Motivation and Emotion, 26(1), 57-81.

Jbarr. (2012, March 20). How Can I Tell If I'm Being Monitored at Work and What Can I Do About It? [Article comment]. http://lifehacker.com/5894689/how-can-i-tell-if-im-being-monitored-at-work-and-whatcan-i-do-about-it

Karakostas, A., \& Zizzo, D. J. (2016). Compliance and the power of authority. Journal of Economic Behavior \& Organization, 124, 67-80.

Kelman, H. C. (1958). Compliance, identification, and internalization three processes of attitude change. Journal of conflict resolution, 2(1), 51-60.

Kenny Powers. (2012, March 26). How To Block Your Employer's Monitoring [Reply to post]. https://www.wallstreetoasis.com/blog/how-to-block-your-employers-monitoring

KPP. (2012, March 26). How To Block Your Employer's Monitoring [Reply to post]. https://www.wallstreetoasis.com/blog/how-to-block-your-employers-monitoring

Langevoort, D. C. (2002). Monitoring: The behavorial economics of corporate compliance with law. Columbia Business Law Review, 71.

Lasprogata, G., \& King, N. J. (2004). Regulation of electronic employee monitoring: Identifying fundamental principles of employee privacy through a comparative study of data privacy legislation in the European Union, United States and Canada. Stanford Technology Law Review, 4. 
Marcellus_wallace. (2013, November 2). How To Block Your Employer's Monitoring [Reply to post].

https://www.wallstreetoasis.com/blog/how-to-block-your-employers-monitoring

Martin, K., \& Freeman, R. E. (2003). Some problems with employee monitoring. Journal of Business Ethics, 43(4), 353-361.

Michael Furman. (2012, March 20). How Can I Tell If I'm Being Monitored at Work and What Can I Do About It? [Article comment].

http://lifehacker.com/5894689/how-can-i-tell-if-im-being-monitored-at-work-and-whatcan-i-do-about-it

Mishra, J. M., \& Crampton, S. M. (1998). Employee monitoring: privacy in the workplace?. SAM Advanced Management Journal, 63(3), 4.

Momoceio. (2012, March 20). How Can I Tell If I'm Being Monitored at Work and What Can I Do About It? [Article comment].

http://lifehacker.com/5894689/how-can-i-tell-if-im-being-monitored-at-work-and-whatcan-i-do-about-it

Monkeybusiness. (2012, March 20). How Can I Tell If I'm Being Monitored at Work and What Can I Do About It? [Article comment].

http://lifehacker.com/5894689/how-can-i-tell-if-im-being-monitored-at-work-and-whatcan-i-do-about-it

Motorola Solutions (2015). MOTOTRBO Enhances Staff Productivity and Safety at The Glades Shopping Cent. November 3, 2016, http://www.motorolasolutions.com/content/dam/msi/docs/products/two-way-radios/ mototrbo/the-glades-case-study.pdf

Muhl, C. J. (2003). Workplace e-mail and Internet use: employees and employers beware. Monthly Labor Review, 126, 36.

Nord, G. D., McCubbins, T. F., \& Nord, J. H. (2006). E-monitoring in the workplace: privacy, legislation, and surveillance software. Communications of the ACM, 49(8), 72-77.

PepsiCo. (n.d.). PepsiCo Global Code of Conduct. March 17, 2017, https://www.pepsico.com/Assets/Download/CodeOfConduct/English_GCOC_2014.pdf 
PricewaterhouseCoopers (2011). Avoiding the Headlines: How Financial Services Firms Can Implement Programs to Prevent Insider Trading. (n.d.). March 13, 2017, https://www.pwc.com/us/en/financial-services/publications/viewpoints/assets/viewpointinsider-trading-prevention.pdf

Rosenblat, A., Kneese, T. \& boyd, d. (2014). Workplace surveillance.

Smith, C., \& Thompson, P. (1998). Re-evaluating the labour process debate. Economic and industrial democracy, 19(4), 551-577.

Solove, D. J. (2007). I've got nothing to hide and other misunderstandings of privacy. San Diego Law Review, 44, 745.

Taylor, F. W. (1914). The principles of scientific management. Harper.

Taylor, P., \& Bain, P. (1999). 'An assembly line in the head': work and employee relations in the call centre. Industrial Relations Journal, 30(2), 101-117.

Teramind. (n.d.a). Employee Monitoring.

March 16, 2017,

https://www.teramind.co/solutions/employee-monitoring

Teramind. (n.d.b). Focus Dashboard.

March 16, 2017,

https://democompany.teramind.co/\#/report/Focus+Dashboard

Twarog, J. (2005). Internet monitoring at work and employee privacy.

November 03, 2016, http://www.massnurses.org/labor-action/labor-education-resources/general-labor/p/ openItem/1211

Verizon. (2015). Code of Conduct. March 17, 2017, https://www.verizon.com/about/sites/default/files/Verizon-Code-of-Conduct.pdf

Veriato. (n.d.). Veriato Features. March 18, 2017, http://www.veriato.com/features\#quickview

Waring, S. P. (1991). Taylorism transformed: scientific management theory since 1945. Chapel Hill: Univ. of North Carolina Press. 
Zipobibrock5e8. (2012, March 20). How Can I Tell If I'm Being Monitored at Work and What Can I Do About It? [Article comment].

http://lifehacker.com/5894689/how-can-i-tell-if-im-being-monitored-at-work-and-whatcan-i-do-about-it 